\title{
The Effect of Organizational Commitment, Moral Leadership, Work Environment, Religiusity and Love of Money Towards Fraud Intention
}

\section{Pengaruh Komitmen Organisasi, Moral Pimpinan, Lingkungan Pekerjaan, Religiusitas dan Love of Money terhadap Fraud Intention}

\author{
Kamelia Astuty \\ Universitas Dehasen Bengkulu \\ Email: 1) kamelia@unived.ac.id
}

How to Cite :

Astuty, K. (2022). The Effect of Organizational Commitment, Moral Leadership, Work Environment, Religiusity and Love of Money Towards Fraud Intention. EMAK: Jurnal Ekonomi Manajemen Akuntansi Dan Keuangan, 3(1). DOI: https://doi.org/10.53697/emak.v3i1

ARTICLE HISTORY

Received [30 Desember 2021]

Revised [02 Januari 2021]

Accepted [20 Januari 2022]

\section{KEYWORDS}

Organizational Commitment,

Leadership Moral, Work

Environment, Religiosity, Love

of Money, Fraud Intention

This is an open access article under the $C C-B Y$-SA license

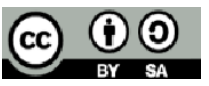

\section{ABSTRAK}

Tujuan penelitian ini untuk membuktikan pengaruh komitmen organisasi, moral pimpinan, lingkungan pekerjaan, religiusitas dan love of money terhadap fraud intention pada karyawan Bank Bengkulu. Jenis penelitian yang digunakan adalah penelitian kuantitatif dengan metode survei. Responden adalah seluruh pegawai/karyawan Bank Bengkulu yang bekerja pada bagian akuntansi dan teller. Pengumpulan data melalui survei online dengan google form, sedangkan analisis data menggunakan model regresi linier berganda. Hasil penelitian menunjukkan bahwa komitmen organisasi berpengaruh negatif terhadap fraud intention. Artinya, semakin tinggi komitmen karyawan terhadap organisasi maka keinginan melakukan kecurangan akan rendah. Moral pimpinan berpengaruh negatif terhadap fraud intention. Artinya, semakin tinggi moral pimpinan maka keinginan melakukan kecurangan akan rendah. Lingkungan pekerjaan berpengaruh negatif terhadap fraud intention. Artinya, semakin baik lingkungan kerja maka keinginan melakukan kecurangan akan rendah. Religiusitas berpengaruh negatif terhadap fraud intention. Artinya, semakin religius seorang karyawan maka keinginan melakukan kecurangan akan rendah. Love of money berpengaruh positif terhadap fraud intention. Artinya, semakin karyawan cinta uang maka keinginan melakukan kecurangan akan tinggi. Penelitian berimplikasi kepada Bank Bengkulu bahwa temuan penelitian didapat love of money tergolong tinggi. Dalam teori Theory of Planned Behavior disebutkan bahwa perilaku timbul karena adanya niat yang melandasi perilaku tersebut (Ajzen, 1991). Intensi inilah yang merupakan awal terbentuknya perilaku seseorang. Oleh sebab itu, manajemen Bank Bengkulu dapat mengurangi fraud intention ini melalui pelatihan karakter (softskill) dengan fokus terhadap core values yang dimiliki oleh Bank Bengkulu.

\section{ABSTRACT}

Many factors influence a person to commit cheating. Several studies have also been conducted to examine matters regarding fraud, both the factors that influence it and the impact it causes. The purpose of this study was to prove the effect of organizational commitment, leadership morale, work environment, religiosity and love of money on fraud intention among Bank Bengkulu employees. This type of research is a quantitative study. 
Respondents are all Bengkulu Bank employees who work in accounting and teller departments. Data collection through online surveys with google form. The results showed that organizational commitment had a negative effect on fraud intention. This means that the higher the employee's commitment to the organization, the lower the desire to commit fraud. Leadership morale has a negative effect on fraud intention. This means that the higher the morale of the leadership, the lower the desire to commit fraud. The work environment has a negative effect on fraud intention. This means that the better the work environment, the lower the desire to commit fraud. Religiosity has a negative effect on fraud intention. This means that the more religious an employee is, the lower the desire to commit fraud. Love of money has a positive effect on fraud intention. This means that the more employees love money, the more likely they are to cheat.

\section{PENDAHULUAN}

Kecurangan (fraud) didefinisikan sebagai suatu kejahatan yang menggunakan penipuan sebagai modus utamanya dan dengan demikian mencakup banyak perilaku menyimpang oleh individu dan organisasi, beberapa diantaranya tidak selalu bersifat kriminal tetapi secara moral meragukan (Wells, 1997). Kecurangan (fraud), jika tidak secara efektif dicegah dan dideteksi, dapat mengakibatkan kerusakan serius pada suatu organisasi. Fraud memiliki sifat yang dinamis sehingga dapat terjadi dimana pun dan kapan pun, tidak hanya fokus pada satu jenis sektor industri saja melainkan dapat terjadi di berbagai jenis sektor industri perusahaan. Association of Certified Fraud Examiners (ACFE), (2016) mengindikasikan bahwa sektor industri perbankan dan jasa keuangan (banking and financial service) sebagai sektor industri yang memiliki frekuensi fraud tertinggi serta organisasi pertama paling dirugikan akibat fraud dibandingkan dengan sektor industri lainnya dengan presentase kerugian sebesar 16.8\%. Otoritas Jasa Keuangan (OJK) (2017) selaku pihak yang menyelenggarakan sistem pengaturan dan pengawasan yang terintegrasi terhadap kegiatan di sektor jasa keuangan secara menyeluruh telah mengungkap 126 kasus terkait dugaan tindak kecurangan perbankan (fraud banking) pada 69 kantor perbankan yang tersebar di seluruh Indonesia dengan modus fraud kejahatan kredit, seperti debitur fiktif, angsuran tidak disetorkan padahal debiturnya sudah membayar, serta modus meminjam uang kas tanpa melalui prosedur perbankan.

Tinjauan yang dilakukan Otoritas Jasa Keuangan (OJK) atas pelaporan tindakan fraud yang diperoleh dari seluruh bank umum di Indonesia, mengindikasikan total kerugian atas tindakan fraud yang terjadi pada tahun 2015 mencapai nilai sebesar Rp.7.071.615.936.801. Nominal tersebut bukanlah suatu hal yang mengejutkan, mengingat Indonesia merupakan salah satu negara dengan potensi fraud tertinggi pada regional Asia Tenggara (Asia Pacific) yaitu menduduki peringkat dua teratas setelah negeri tirai bambu Cina sebagaimana dinyatakan Association of Certified Fraud Examiners dalam Report to The Nations pada tahun 2016. Sebagaimana dinyatakan pula bahwa total kerugian yang ditimbulkan akibat terjadinya kasus fraud pada seluruh sektor industri di Indonesia menunjukkan angka 42 dengan jenis fraud terbanyak ditemukan dalam bentuk asset misappropriation terjadi lebih dari $83 \%$ kasus dan lebih dari $50 \%$ kasus fraud yang terjadi pada seluruh sektor industri dan telah dilaporkan berasal dari sektor industri perbankan (Association-ofCertified-Fraud-Examiners-(ACFE), 2016).

Survei yang dilakukan oleh Ernst \& Young dalam Survei Fraud Indonesia (SFI) yang berpedomankan pada pola survei yang dilakukan oleh ACFE - Global Fraud Study dalam Report to The Nation (2016) menyatakan bahwa motivasi fraudster untuk melakukan fraud dikarenakan adanya keinginan untuk berperilaku berkehidupan mewah (extravaganza life style). Terungkapnya berbagai macam kasus fraud di media massa telah memperlihatkan bahwa industri perbankan menjadi lebih rentan terhadap fraud dalam beberapa tahun terakhir, meskipun sejumlah strategi 
dalam mengendalikan fraud telah diimplementasikan secara maksimal. Kasus fraud yang terjadi pada PT. Bank Tabungan Negara (BTN) cabang cikeas pada tahun 2016 terkait kasus pemalsuan bilyet giro deposito yang telah mengakibatkan BTN harus menderita kerugian sebesar Rp 258 milyar. Kemudian, kasus pembobolan tujuh bank terkait modus kredit fiktif PT. Rockit Aldeway (2017) dimana dalam kasus kredit fiktif Aldeway, tindakan fraud telah menimbulkan kerugian mencapai Rp 846 miliar. Serta kasus fraud Malinda Dee pada Citibank yang menjabat sebagai relationship manager citigold dengan modus pencucian uang mencapai kerugian senilai $\mathrm{Rp} 40$ miliar. Hal tersebut menunjukkan bahwa meskipun Bank Indonesia telah menetapkan strategi antifraud sebagaimana dinyatakan dalam Surat Edaran Bank Indonesia No.13/28/DPNP per tanggal 9 Desember 2011, kasus fraud masih kerap ditemukan di industri perbankan.

Banyak faktor-faktor yang mempengaruhi seseorang untuk melakukan kecurangan. Beberapa penelitian pun juga telah dilakukan untuk meneliti hal-hal mengenai kecurangan, baik itu faktor yang mempengaruhi maupun dampak yang ditimbulkannya. Penelitian awal yang menguji love of money (kecintaan terhadap uang) pertama kali dilakukan oleh Tang dan Chiu (2003) dimana mereka membuktikan bahwa kecintaan terhadap uang merupakan persoalan mendasar dari fraud dan kecintaan terhadap uang merupakan variabel mediator atas perilaku tidak etis (Sardzoska \& Tang, 2011). Selanjutnya Tang dan Chiu (2003) juga membuktikan komitmen organisasi karyawan tidak akan terkait dengan fraud jika karyawan memiliki kepuasan tinggi dengan gaji yang mereka terima.

Penelitian yang dilakukan oleh Sardzoska dan Tang (2011) dengan menggunakan pendekatan teori perilaku yang direncanakan untuk mengidentifikasi beberapa faktor yang mempengaruhi niat karyawan untuk melakukan fraud. Sardzoska dan Tang (2011) menggunakan variabel lingkungan kerja untuk mengidentifikasi efek dari lingkungan kerja dilihat dari tiga dimensi: (1) reliationship, (2) pertumbuhan pribadi atau orientasi tujuan, dan (3) pemeliharaan dan perubahan sistem.

Moral pimpinan juga mempengaruhi intensi kecurangan, Mayer dan Greenbaum (2010) telah menguji hubungan antara moral pemimpin terhadap perilaku yang menyimpang, dimana mereka mendapatkan bahwa moral pemimpin berpengaruh negatif terhadap perilaku menyimpang. Moral pimpinan adalah perilaku yang pantas secara normatif sehingga mereka tampak jujur dan dapat dipercaya oleh orang lain. Moral pimpinan berarti bahwa pemimpin secara terbuka dan eksplisit berbicara tentang etika dan mempengaruhi perilaku dan kepercayaan karyawan (Ciulla, 1995).

Lingkungan kerja mempengaruhi tingkat intensi kecurangan, lingkungan yang penuh dengan kecurangan mempengaruhi tingkah laku karyawan. Seseorang yang terlibat dalam satu lingkungan akan meniru apa yang dilihat orang di lingkungan itu (Taiwo, 2009). Amabile et al., (1996) menemukan bukti bahwa pada suatu lingkungan kerja yang menguntungkan menciptakan kreativitas, perilaku etis dan kinerja bagi para karyawan akan sulit untuk berperilaku curang. Lingkungan kerja yang menguntungkan akan meningkatkan kepuasan kerja dan mampu menurunkan perilaku curang.

Penelitian ini mencoba mengeksplorasi dan mengidentifikasi faktor-faktor yang mempengaruhi karyawan untuk melakukan fraud intention dengan menggunakan beberapabeberapa faktor love of money, komitmen organisasi, moral pimpinan, lingkungan pekerjaan, dan religiusitas. Penelitian ini merupakan replikasi atas penelitian yang dilakukan oleh Wicaksono dan Urumsah (2016) yang menguji beberapa faktor yang mempengaruhi keinginan karyawan non medikal untuk melakukan fraud.

\section{LANDASAN TEORI}

\section{Grand Theory}

Teori yang digunakan dalam penelitian adalah Theory of Planned Behavior (TPB). Teori ini dapat digunakan untuk menilai dan mengukur keinginan melakukan kecurangan. Teori ini 
menjelaskan bahwa perilaku timbul karena adanya niat yang melandasi perilaku tersebut (Ajzen, 1991). Intensi inilah yang merupakan awal terbentuknya perilaku seseorang. Theory of planned behavior cocok digunakan untuk mendeskripsikan perilaku apapun yang memerlukan perencanaan (Ajzen, 1991). Menurut Ajzen (1991) keinginan untuk melakukan sesuatu mempengaruhi keputusan individu untuk melakukan suatu perilaku, semakin kuat keinginan individu untuk berperilaku curang maka besar kemungkinan niat tersebut diaktualisasikan dalam bentuk suatu perilaku.

\section{Kecurangan (Fraud)}

Fraud atau kecurangan adalah segala tindakan yang disengaja untuk berbuat kecurangan atau penipuan yang dapat merugikan orang lain. Fraud ini biasanya dilakukan untuk mendapatkan keuntungan pribadi atau sekelompok orang tertentu. Menurut Association of Certified Fraud Examiners (2014) kecurangan (fraud) didefinisikan sebagai penggunaan dari suatu kedudukan untuk memperkaya pribadi dengan cara penyalahgunaan yang dilakukan dengan sengaja terhadap penggunaan sumber daya atau aset milik perusahaan.

Menurut Tuanakotta (2007) kecurangan adalah setiap tindakan ilegal yang ditandai dengan penipuan, penyembunyian, atau ancaman kepercayaan. Tindakan ini tidak tergantung pada penerapan ancaman kekerasan atau kekuatan fisik. Penipuan dilakukan oleh individu, dan organisasi untuk mendapatkan uang, properti, atau layanan untuk menghindari pembayaran atau kehilangan layanan, atau untuk mengamankan keuntungan bisnis pribadi. Arens, et al. (2012) menjelaskan bahwa fraud mencakup: "Penggelapan, manipulasi pelanggaran karena jabatan, pencurian, ketidakjujuran, kelakuan buruk, kelalaian, penggelapan pajak, penyuapan, pemerasan, penyerobotan, salah saji". Tidak jauh berbeda dengan (Ziegenfuss, 1996), fraud dapat dalam berbagai bentuk, seperti penggelapan, perdagangan orang dalam, perdagangan sendiri, berbohong, kegagalan untuk mengungkapkan fakta, korupsi, manipulasi akun, suap, vendor hantu, dan banyak lagi.

\section{Komitmen Organisasi}

Meyer dan Allen dalam (Suharto \& Suyanto, 2019) mendefinisikan dimana komitmen organisasi sebagai sebuah keadaan psikologi yang mengkarakteristikkan hubungan karyawan dengan organisasi atau implikasinya yang mempengaruhi apakah karyawan akan tetap bertahan dalam organisasi atau tidak, yang teridentifikasi dalam tiga komponen yaitu: komitmen afektif, komitmen berkelanjutan dan komitmen normatif.

Komitmen pada organisasi tersebut juga membahas kedekatan karyawan terhadap organisasi dimana mereka berada dan sekaligus komitmen merefleksikan kekuatan keterlibatan dan kesetiaan karyawan pada organisasi. Keterlibatan dan kesetiaan ini sangat dipengaruhi oleh seberapa besar pekerjaan yang dibebankan pada karyawan sesuai dengan harapan mereka (Chen, et al., 2018)

Definisi lainnya dikemukakan oleh (Robbins \& Judge, 2013) yaitu keterlibatan pekerjaan yang tinggi berarti memihak pada pekerjaan tertentu, sementara komitmen organisasional yang tinggi berarti memihak organisasi yang merekrut individu tersebut. Pernyataan tersebut juga diperkuat oleh apa yang dikemukakan oleh (Lapointe \& Vandenberghe, 2018) yang menyatakan bahwa komitmen organisasional merupakan tingkat dimana individu memihak dan ingin secara berkelanjutan berpartisipasi aktif dalam organisasi, yang tercermin melalui karakteristikkarakteristik sebagai berikut: (1) Adanya keyakinan yang kuat dan penerimaan atas nilai dan tujuan organisasi, (2) Kesediaan untuk mengusahakan yang terbaik bagi organisasi, dan (3) Adanya keinginan yang pasti untuk bertahan dalam organisasi. Komitmen organisasional ialah kedekatan karyawan dengan organisasi dimana mereka berada, ada juga yang menyatakan komitmen adalah keterlibatan \& kesetiaan karyawan terhadap organisasi (Al-Madi, et al., 2017) 


\section{METODE PENELITIAN}

Jenis penelitian yang digunakan dalam penelitian ini adalah penelitian kuantitatif dengan metode survei. Penelitian kuantitatif dengan metode survei adalah penelitian yang dilakukan pada populasi besar ataupun kecil data yang dipelajari adalah data dari sampel yang diambil dari populasi tersebut (Sugiyono, 2012). Jenis data yang digunakan dalam penelitian ini adalah data primer. Data dikumpulkan melalui metode angket, yaitu menyebar daftar pertanyaan (kuesioner).

Penelitian ini menggunakan analisis regresi partial untuk menguji kelima hipotesis yang diajukan dalam penelitian ini. Masing-masing hipotesis akan dianalisis menggunakan software SPSS untuk menguji hubungan antar variabel. Teknik analisis yang digunakan dalam penelitian ini adalah teknik regresi linier berganda yaitu suatu model linier regresi yang variabel dependennya merupakan fungsi linier dari beberapa variabel bebas. Teknik analisis ini bermanfaat untuk memperoleh gambaran yang menyeluruh mengenai hubungan antara variabel satu dengan variabel lain. Regresi linier berganda sangat dibutuhkan dalam berbagai pengambilan keputusan baik dalam perumusan kebijakan manajemen maupun dalam telaah ilmiah. Persamaan regresi berdasarkan kerangka analisis yang telah ditulis adalah sebagai berikut:

$$
Y=\alpha+\beta_{1} X_{1}+\beta_{2} X_{2}+\beta_{3} X_{3}+\beta_{4} X_{4}+\beta_{5} X_{5}+e
$$

Keterangan:

$\begin{array}{ll}\mathrm{Y} & =\text { Fraud Intention } \\ \mathrm{a} & =\text { Konstanta } \\ \beta & =\text { Koefisien Regresi Linier Berganda } \\ \mathrm{e} & =\text { Kesalahan Residual (error) } \\ \mathrm{X}_{1} & =\text { Komitmen Organisasi } \\ \mathrm{X}_{2} & =\text { Moral Pimpinan } \\ \mathrm{X}_{3} & =\text { Lingkungan Pekerjaan } \\ \mathrm{X}_{4} & =\text { Religuitas } \\ \mathrm{X}_{5} & =\text { Love of Money }\end{array}$

HASIL DAN PEMBAHASAN

Model linier regresi bertujuan untuk memperoleh gambaran yang menyeluruh mengenai arah pengaruh variabel komitmen organisasi, moral pimpinan, lingkungan pekerjaan, religiusitas, love of money terhadap fraud intention. Hasil analisis regresi linier berganda adalah sebagai berikut:

Tabel 1. Hasil Uji Regresi Linier Berganda

\begin{tabular}{|l|c|c|c|c|c|c|}
\hline \multirow{2}{*}{ Model } & \multicolumn{2}{c|}{$\begin{array}{c}\text { Unstandardized } \\
\text { Coefficients }\end{array}$} & $\begin{array}{c}\text { Standardized } \\
\text { Coefficients }\end{array}$ & t & Sig. & Kesimpulan \\
\cline { 2 - 8 } & B & Std. Error & Beta & & & \\
\hline (Constant) & 0,922 & 1,499 & & 2,080 & 0,040 & \\
\hline Komitmen Organisasi & $-0,176$ & 0,248 & $-0,148$ & $-2,305$ & 0,030 & Diterima \\
\hline Moral Pimpinan & $-0,112$ & 0,285 & $-0,147$ & $-4,392$ & 0,003 & Diterima \\
\hline Lingkungan Kerja & $-0,229$ & 0,256 & $-0,216$ & $-3,114$ & 0,010 & Diterima \\
\hline Religuitas & $-0,315$ & 0,284 & $-0,127$ & $-3,112$ & 0,012 & Diterima \\
\hline Love of Money & 0,309 & 0,202 & 0,165 & 4,531 & 0,009 & Diterima \\
\hline
\end{tabular}

Sumber : Hasil Olah Data SPSS, Lampiran 20

Uji t dilakukan untuk mengetahui pengaruh komitmen organisasi, moral pimpinan, lingkungan pekerjaan, religiusitas, love of money terhadap fraud intention. Berdasarkan Tabel 4.10 
dari hasil pengujian statistik variabel komitmen organisasi menunjukkan signifikasi variabel komitmen organisasi 0,030<0,05 dan koefisien regresi variabel komitmen bernilai negatif, hal ini menunjukkan terdapat pengaruh negatif dari variabel komitmen organisasi terhadap fraud intention, dengan demikian hipotesis alternatif ( $\mathrm{Ha} 1)$ yang menyatakan komitmen organisasi berpengaruh negatif terhadap fraud intention dapat Diterima. Artinya, semakin tinggi komitmen karyawan terhadap organisasi maka keinginan melakukan kecurangan akan rendah. Sebaliknya, semakin rendah komitmen terhadap organisasi maka keinginan melakukan kecurangan akan semakin tinggi.

Tabel 1. menunjukkan bahwa variabel moral pimpinan berpengaruh terhadap fraud intention. Hasil pengujian statistik variabel moral pimpinan memiliki signifikasi sebesar 0,003<0,05 dan koefisien regresi variabel moral pimpinan bernilai negatif, hal ini menunjukkan bahwa variabel moral pimpinan memiliki arah pengaruh negatif terhadap fraud intention. Dengan demikian hipotesis alternatif ( $\mathrm{Ha} 2$ ) yang menyatakan moral pimpinan berpengaruh negatif terhadap fraud intention Diterima. Artinya, semakin tinggi moral pimpinan maka keinginan melakukan kecurangan akan rendah. Sebaliknya, semakin rendah moral pimpinan maka keinginan melakukan kecurangan akan semakin tinggi.

Pengujian statistik untuk variabel lingkungan pekerjaan berdasarkan tabel 1. menunjukkan variabel lingkungan pekerjaan berpengaruh negatif terhadap fraud intention. Nilai signifikansi $t$ untuk variabel fraud intention sebesar $0,010<0,05$ dan koefisien regresi variabel lingkungan pekerjaan bernilai negatif, hal ini menunjukkan terdapat pengaruh negatif dari variabel lingkungan pekerjaan terhadap fraud intention. Dengan demikian hipotesis alternatif (Ha3) yang menyatakan lingkungan pekerjaan berpengaruh negatif terhadap fraud intention Diterima. Artinya, artinya semakin baik lingkungan kerja di Bank Bengkulu maka keinginan melakukan kecurangan akan rendah. Sebaliknya, semakin buruk lingkungan kerja di Bank Bengkulu maka keinginan melakukan kecurangan akan semakin tinggi.

Tabel 1. menunjukkan bahwa variabel religiusitas berpengaruh terhadap fraud intention. Hasil pengujian statistik menunjukkan bahwa variabel religiusitas dengan signifikasi sebesar 0,012< 0,05 dan koefisien regresi variabel religiusitas bernilai negatif, hal ini menunjukkan bahwa variabel religiusitas memiliki arah pengaruh negatif terhadap fraud intention. Dengan demikian hipotesis alternatif ( $\mathrm{Ha} 4)$ yang menyatakan religiusitas berpengaruh negatif terhadap fraud intention Diterima. Artinya, semakin religius seorang karyawan maka keinginan melakukan kecurangan akan rendah. Sebaliknya, semakin kurang religius seorang karyawan maka keinginan melakukan kecurangan akan semakin tinggi.

Tabel 1. menunjukkan bahwa variabel love of money berpengaruh terhadap fraud intention. Hasil pengujian statistik menunjukkan bahwa variabel love of money dengan signifikasi sebesar 0,009 $<0,05$ dan koefisien regresi variabel love of money bernilai positif, hal ini menunjukkan bahwa variabel love of money memiliki arah pengaruh positif terhadap fraud intention. Dengan demikian hipotesis alternatif ( $\mathrm{Ha5}$ ) yang menyatakan love of money berpengaruh positif terhadap fraud intention Diterima. Artinya, semakin karyawan cinta uang maka keinginan melakukan kecurangan akan tinggi. Sebaliknya, semakin karyawan kurang cinta uang maka keinginan melakukan kecurangan akan semakin rendah.

\section{PEMBAHASAN}

Sub bagian pembahasan ini menjelaskan hasil penelitian pengaruh antar variabel, yaitu pengaruh komitmen organisasi, moral pimpinan, lingkungan pekerjaan, religiusitas, love of money terhadap fraud intention.

\section{Pengaruh Komitmen Organisasi terhadap Fraud Intention}

Berdasarkan hasil penelitian didapat bahwa komitmen organisasi berpengaruh negatif terhadap fraud intention. Artinya, semakin tinggi komitmen karyawan terhadap organisasi maka keinginan melakukan kecurangan akan rendah. Sebaliknya, semakin rendah komitmen karyawan terhadap organisasi maka keinginan melakukan kecurangan akan semakin tinggi. Hasil ini 
mendukung penelitian Tang dan Chiu (2003); Zulaikha dan Hadiprajitno (2016) dalam penelitiannya menemukan pengaruh negatif komitmen organisasi terhadap perilaku curang, salah satu faktor yang mempengaruhi kecurangan adalah karyawan yang memiliki komitmen organisasi rendah.

Komitmen organisasi pada penelitian ini termasuk dalam penilaian tinggi. Artinya, komitmen karyawan terhadap Bank Bengkulu adalah tinggi, mereka merasa menjadi bagian dari keluarga Bank Bengkulu dan merasa bahwa Bank Bengkulu telah banyak berjasa bagi hidup mereka. Komitmen organisasi merupakan keadaan dimana seorang karyawan memihak pada satu organisasi dan tujuan-tujuannya, serta berniat untuk memelihara keanggotaannya dalam organisasi tersebut (Robbins \& Judge, 2013). Ketika karyawan memiliki komitmen organisasi, maka karyawan akan memiliki keterikatan emosional dan penyesuaian nilai-nilai dengan organisasi yang nantinya berdampak pada suatu tindakan positif untuk kemajuan organisasi.

Keinginan melakukan kecurangan merupakan tindakan yang sudah direncanakan sebelumnya. Keputusan untuk melakukan atau tetap diam melihat adanya kecurangan dilandasi oleh niat yang timbul dari individu (Ajzen, 2012). Karyawan yang memiliki komitmen organisasi yang rendah, cenderung akan mencari kelemahan sistem perusahaan untuk mengambil keuntungan. Perilaku curang berarti karyawan memiliki komitmen organisasi yang rendah dan tidak mencintai tempat kerjanya.

\section{Pengaruh Moral Pimpinan terhadap Fraud Intention}

Hasil penelitian menunjukkan bahwa moral pimpinan berpengaruh negatif terhadap fraud intention. Artinya, semakin tinggi moral pimpinan maka keinginan melakukan kecurangan akan rendah. Sebaliknya, semakin rendah moral pimpinan maka keinginan melakukan kecurangan akan semakin tinggi. Hasil ini sejalan dengan Mayer dan Greenbaum (2010); Kurniawan (2013) yang juga menemukan berpengaruh negatif moral pimpinan terhadap perilaku menyimpang.

Moral pimpinan pada Bank Bengkulu dalam penilaian baik, hasil ini sesuai dengan salah satu core values perusahaan bahwa karyawan harus membangun kepercayaan dengan kejujuran, tanggung jawab, dan melaksanakan tugas dengan dedikasi yang tinggi, serta menjunjung tinggi dan menaati kode etik Bankir. Kepemimpinan sebagai dorongan untuk mencapai tujuan organisasi, maka pemimpin harus memiliki sesuatu yang dapat mempengaruhi orang lain untuk mencapai tujuannya. Pemimpin tidak hanya harus memiliki kompetensi tetapi juga harus bermoral (Ciulla, 1995). Pemimpin harus menunjukkan standar perilaku moral dan etika tertinggi dalam setiap hari dalam pembicaraan, perilaku, tindakan, dan membuat keputusan sehingga orang lain dalam organisasi dapat mengikuti (Toor dan Ofori, 2009).

Trongmateerut \& Sweeney (2012), mengatakan bahwa faktor yang dapat mempengaruhi niat seseorang didasari oleh teori Reasoned Action atau sikap dan norma subjektif orang tersebut. Moral merupakan perilaku yang pantas secara normatif sehingga mereka tampak jujur, dapat dipercaya oleh orang lain. Moral pimpinan berarti bahwa pemimpin secara terbuka dan eksplisit berbicara tentang etika dan mempengaruhi perilaku dan kepercayaan karyawan (Ciulla, 1995). Artinya, pimpinan yang memiliki moral yang baik akan cenderung jujur, dapat dipercaya, dan menjauh dari perilaku curang.

\section{Pengaruh Lingkungan Pekerjaan terhadap Fraud Intention}

Hasil penelitian didapatkan bahwa lingkungan pekerjaan berpengaruh negatif terhadap fraud intention. Artinya, artinya semakin baik lingkungan kerja di Bank Bengkulu maka keinginan melakukan kecurangan akan rendah. Sebaliknya, semakin buruk lingkungan kerja di Bank Bengkulu maka keinginan melakukan kecurangan akan semakin tinggi. Hasil ini mendukung Sardzoska dan Tang (2011), bahwa pada lingkungan kerja yang kurang baik dan budaya kerja yang jelek akan menciptakan perilaku curang karyawan. Dengan demikian dapat dinyatakan bahwa karyawan yang terlibat dalam satu lingkungan yang penuh kecurangan akan meniru apa yang dilihat karyawan di lingkungan itu. 
Lingkungan kerja di Bank Bengkulu termasuk dalam penilaian yang baik, seperti keamanan terjamin sehingga karyawan merasa aman dan nyaman bekerja, suasana kerja di Bank Bengkulu berjalan kondusif. Lingkungan kerja menggambarkan bagaimana situasi di tempat kerja mempengaruhi tingkah laku karyawan. Seseorang yang terlibat dalam satu lingkungan akan meniru apa yang dilihat orang di lingkungan itu. Amabile et al., (1996) menemukan bukti bahwa pada suatu lingkungan kerja baik, intensi kecurangan karyawan akan rendah.

Sikap kepada perilaku (attitude toward behavior) adalah evaluasi seseorang secara positif atau negatif, termasuk kepada lingkungan (Ajzen, 2012). Menurut Anggar \& Ratnadi (2017) sikap individu terhadap suatu perilaku diperoleh dari keyakinan terhadap konsekuensi yang ditimbulkan perilaku tersebut sehingga apabila seseorang melakukan perilaku yang menghasilkan outcome positif, maka individu tersebut memiliki sikap positif, begitu juga sebaliknya

Kontrol perilaku dapat juga diartikan sebagai pemahaman mengenai sederhana atau kompleksnya dalam melakukan perbuatan atas dasar pada lingkungannya. Individu akan melakukan perilaku jika sudah melakukan evaluasi secara positif terhadap perilaku tersebut, terdapat pengaruh lingkungan untuk melakukan suatu perilaku, serta adanya kepercayaan individu terhadap perilaku tersebut (Aijzen, 2012). Pegawai yang bekerja pada lingkungan kerja yang tidak mendukung (curang), pada akhirnya akan merasa tertekan dan berkeinginan untuk curang. Jika pun ia benar, tetapi dalam lingkungan yang curang akan menjadi salah.

\section{Pengaruh Religiusitas terhadap Fraud Intention}

Berdasarkan hasil penelitian diketahui bahwa religiusitas berpengaruh negatif terhadap fraud intention. Artinya, semakin religius seorang karyawan maka keinginan melakukan kecurangan akan rendah. Sebaliknya, semakin kurang religius seorang karyawan maka keinginan melakukan kecurangan akan semakin tinggi. Hasil ini sejalan dengan Yilmaz dan Bahcekapili (2015) menemukan bahwa religuitas berpengaruh negatif terhadap perilaku curang, dimana dalam suatu keyakinan dalam beragama ada larangan untuk melakukan tindakan curang karena itu adalah dosa. Penelitian ini juga mendukung Egita (2019); Jaelani (2020); Herlyana, et al. (2017) mendapatkan pengaruh negatif religiusitas dengan kecurangan. Seseorang dengan religuitas yang tinggi tidak melakukan perilaku curang yang dilarang oleh agama mereka.

Religuitas karyawan Bank Bengkulu dalam penilaian yang tinggi, mereka melaksanakan ritual keagamaan, memahami hakikat dan aplikasi dalam beragama. Religiusitas pada umumnya terdapat sesuatu yang dirasakan sangat dalam dan bersentuhan dengan keinginan seseorang, membutuhkan ketaatan dan memberikan imbalan atau mengikat seseorang dalam suatu masyarakat (Nashori \& Mucharam, 2002). Religiusitas merupakan gambaran keadaan dalam diri seseorang yang mendorongnya bertingkah laku (baik tingkah laku yang tampak maupun tak tampak), bersikap, dan bertindak sesuai dengan ajaran-ajaran agama yang dianutnya.

Seluruh ajaran agama pasti mengajarkan kebaikan dan melarang perilaku curang. Karyawan yang tampak religius, tidak akan berbuat curang. Tapi pernyataan ini tidak sepenuhnya benar, karena menurut Menurut Ajzen (1991) keinginan untuk melakukan sesuatu mempengaruhi keputusan individu untuk melakukan suatu perilaku, semakin kuat keinginan individu untuk berperilaku curang maka besar kemungkinan niat tersebut diaktualisasikan dalam bentuk suatu perilaku.

\section{Pengaruh Love of Money terhadap Fraud Intention}

Hasil penelitian didapatkan bahwa love of money berpengaruh positif terhadap fraud intention. Artinya, semakin karyawan cinta uang maka keinginan melakukan kecurangan akan tinggi. Sebaliknya, semakin karyawan kurang cinta uang maka keinginan melakukan kecurangan akan semakin rendah. Hasil ini mendukung Tang dan Chiu (2003); Tang et al., (2004), menemukan bahwa kecintaan atas uang (love of money) adalah akarnya dari kejahatan (perilaku curang). Hal ini dibuktikan dengan hasil penelitiannya yang menyimpulkan para pekerja yang lebih menyukai uang 
merasa tidak cukup puas atas pembayaran dari gaji yang mereka terima dan cenderung berperilaku curang.

Love of money pada karyawan Bank Bengkulu termasuk dalam penilaian tinggi. Artinya bahwa karyawan Bank Bengkulu memiliki cinta yang cukup berlebihan terhadap uang, mereka terdorong untuk mendapatkan lebih banyak uang atas pekerjaan yang dilakukan. Love of money dapat digunakan sebagai motivator kejahatan (fraud) (Sardzoska dan Tang, 2011; Tang dan Chiu, 2003). Cinta akan uang (love money) didefinisikan sebagai perilaku terhadap uang dari individu termasuk afektif, perilaku, dan komponen kognitif. Arti cinta uang adalah aspirasi atau obsesi terhadap uang (Sardzoska dan Tang, 2011).

Apabila individu meyakini dan menyetujui dirinya melakukan suatu perilaku dan termotivasi mengikuti suatu perilaku, maka individu tersebut dianggap merasakan tekanan sosial, begitu pula sebaliknya (Ajzen, 2012). Hal ini sejalan dengan penelitian Hamilton, et al. (2011) tentang tekanan sosial berhubungan dengan keputusan seseorang untuk melakukan atau tidak melakukan perilaku. Tekanan keuangan biasanya terkait langsung dengan pelaku, seperti sifat serakah, gaya hidup mewah, tagihan dan utang yang tinggi, kerugian keuangan pribadi serta kebutuhan keuangan yang tak terduga (Zimbelman, 2014).

\section{KESIMPULAN DAN SARAN}

\section{Kesimpulan}

1. Komitmen organisasi berpengaruh negatif terhadap fraud intention. Artinya, semakin tinggi komitmen karyawan terhadap organisasi maka keinginan melakukan kecurangan akan rendah. Sebaliknya, semakin rendah komitmen karyawan terhadap organisasi maka keinginan melakukan kecurangan akan semakin tinggi.

2. Moral pimpinan berpengaruh negatif terhadap fraud intention. Artinya, semakin tinggi moral pimpinan maka keinginan melakukan kecurangan akan rendah. Sebaliknya, semakin rendah moral pimpinan maka keinginan melakukan kecurangan akan semakin tinggi.

3. Lingkungan pekerjaan berpengaruh negatif terhadap fraud intention. Artinya, artinya semakin baik lingkungan kerja di Bank Bengkulu maka keinginan melakukan kecurangan akan rendah. Sebaliknya, semakin buruk lingkungan kerja di Bank Bengkulu maka keinginan melakukan kecurangan akan semakin tinggi.

4. Religiusitas berpengaruh negatif terhadap fraud intention. Artinya, semakin religius seorang karyawan maka keinginan melakukan kecurangan akan rendah. Sebaliknya, semakin kurang religius seorang karyawan maka keinginan melakukan kecurangan akan semakin tinggi.

5. Love of money berpengaruh positif terhadap fraud intention. Artinya, semakin karyawan cinta uang maka keinginan melakukan kecurangan akan tinggi. Sebaliknya, semakin karyawan kurang cinta uang maka keinginan melakukan kecurangan akan semakin rendah.

\section{Saran}

Peneliti selanjutnya dapat menjadikan menggali lebih jauh dan lebih dalam bagian-bagian yang terkait atau berpotensi untuk terjadi fraud, sehingga hasil penelitian dapat digeneralisasi ke semua pegawai dan tidak bias.

\section{DAFTAR PUSTAKA}

Abdullah, I. \& Rashid, Y., 2017. Effect of personality on organizational commitment and employees' performance: Empirical evidence from banking sector of Pakistan. World Applied Sciences Journal, 27(1), pp. 140-147. 
Abun, D., Racoma, A. \& Racsa, L., 2017. Moral Leadership of Middle-Lower Level Managers and Employee's Job Satisfaction of Divine Word Colleges in Region I, Philippines as Perceived by the Employees. Journal of Business Management, 3(9), pp. 257-288.

Ajzen, I., 1991. The Theory of Planned Behavior. Organizational Behavior and Human Decision Processes, 50(6), pp. 179-211.

Ajzen, I., 2012. Attitudes, Personality and Behavior. New York: Open University Press.

Albrecht, W. S., 2012. Fraud Examination. South-Western: Cengage Learning.

Allen, N. J. \& Meyer, J. P., 1990. The measurement and antecedents of affective, continuance, and normative commitment to the organization. Journal of Occupational Psychology, 63(2), pp. 1. 18.

Al-Madi, F., Assal, H., Shrafat, F. \& Zeglat, D., 2017. The Impact of Employee Motivation on Organizational Commitment. Journal of Business Management, 9(15), pp. 134-145.

Amabile, T. M. et al., 1996. Assessing the work environment for creativity. The Academy of Management Journal, 39(5), pp. 154-1184.

Ancok, D. \& Suroso, F. N., 2001. Psikologi Islami. Yogyakarta: Pustaka Pelajar.

Ancona, D., Malone, T., Orlikowski, W. \& Senge, P., 2007. In Praise of the Incomplete Leader. Harvard Business Review, 85(2), pp. 92-100.

Andisti, M. A. \& Ritandiyono, 2008. Religiusitas dan Perilaku Seks Bebas Pada Dewasa Awal. Jurnal Psikologi, 1(2), pp. 170-176.

Arens, A., Randal, J., Elder, M. \& Beasley, S., 2012. Auditing and. Assurance Services: An Integrated Approach. Pearson: Prentice Hall.

Association-of-Certified-Fraud-Examiners-(ACFE), 2016. Report to the Nations on Occuptional Fraud and Abuse. Global Fraud Study. [Online]

Available at: www.acfe.com

[Diakses 28 September 2020].

Bakhshi, A., Kumar, K. \& Rani, E., 2009. Organizational justice perception as predictor of job satisfaction and organizational commitment. International Journal of Business and Management, 4(9), pp. 145-154.

Bass, B. M., 1985. Leadership and performance beyond expectations. New York: Free Press.

Basuki \& Susilowati, 2005. Dampak Kepemimpinan dan Lingkungan Kerja terhadap Semangat Kerja. Jurnal JRBI, 1(1), pp. 12-14.

Bennis, W., 2010. On Becoming a Leader. Jakarta: Alex Media.

Beukhof, G., Jong, M. J. D. \& Nijhof, W. J., 2018. Employee commitment in changing organization: An exploration. Journal of European Industrial Training, 22(6), pp. 243-248.

Biddle, C., 2013. The Objective Standards. Richmond: Glen Allen Press.

Biswas, S., 2009. Organizational culture and transformational leadership as predictors of employee performance. Indian Journal of Industrial relations, 44(4), pp. 611-627.

Burns, J. M. G., 1978. Leadership. New York: Harper \& Row.

Chan, L. \& Bishop, B., 2013. A moral basis for recycling: extending the theory of planned behavior. Journal of Environmental Psychology, 36(6), pp. 96-102.

Chen, Y., Zhou, X. \& Klyver, K., 2018. Collective efficacy: Linking paternalistic leadership to organizational commitment. Journal of Business Ethics, 2(2), pp. 1-17.

Ciulla, J. B., 1995. Leadership ethics: mapping. Business Ethic Quarterly, 5(1), pp. 5-28.

Cohen, J. D. C., Lesage \& Stolowy, H., 2010. Corporate Fraud and Managers' Behavior: Evidence from the Press. Journal of Business Ethics, 95(11), pp. 271-315.

Condit, C. M. \& Caudil, S., 1999. Contemporary rhetorical theory: a reader. New York: Guilford Press.

Covey, S. M. R., 2009. How the Best Leaders Build Trust. [Online]

Available at: http://www.leadershipnow.com/CoveyOnTrust.html

[Diakses 28 September 2020].

Creswell, J. W. \& Clark, V. L. P., 2011. and Conducting Mixed Methods Research. Amerika: SAGE. 
Croall, H., 2007. Victims of white collar and corporate crime. In: Davies P, Francis P and Greer C (eds). Victims, Crime and Society, 6(2), pp. 78-108.

Danang, S., 2012. Manajemen Sumber Daya Manusia. Jakarta: Buku Seru.

Egita, E., 2019. Pengaruh Religiusitas, Reward and Punishment, dan Job Rotation terhadap Fraud (Studi Pada Karyawan BMT di Kabupaten Wonosobo). Jurnal Penelitian dan Pengabdian Kepada Masyarakat, 7(1), pp. 55-64.

Elias, R. Z., 2010. The Relationship Between Accounting Student Love Of Money and Their Ethical Perception. Managerial Auditing Journal, 25(3), pp. 17-26.

Fieser, J., 2002. Ethics, in Internet Encyclopedia. [Online]

Available at: http://www.iep.utm.edu/ethics/

[Diakses 28 September 2020].

Fishbein, M. \& Ajzen, I., 2010. Predicting and Changing Behavior: The Reasoned Action Approach. New York: Psychology Press.

Ghozali, I., 2006. Aplikasi Analisis Multivariate Dengan Program SPSS. 2nd penyunt. Semarang: Badan Penerbit Universitas Diponegoro.

Ghozali, I., 2006. Aplikasi Analisis Multivariate Dengan Program SPSS. Semarang: Badan Penerbit Universitas Diponegoro.

Glock, C. Y. \& Stark, R., 1965. Religion and Society in Tension. San Fransisco: Rand McNally.

Glover, H. D. \& Aono, J. Y., 1995. Changing the Model for Prevention and Detection of Fraud. Managerial Auditing Journal, 10(5), pp. 3-9.

Hair, J. F., Black, W. C., Babin, B. J. \& Anderson, R. E., 2010. Multivariate Data Analysis. New Jersey: Prentice Hall.

Heider, F. \& Simmel, M., 1958. An experimental study of apparent behavior. The American Journal of Psychology, 57(2), pp. 243-259.

Herlyana, M. V., Sujana, E. \& Prayudi, M., 2017. Pengaruh Rreliguitas dan Spiritualitas terhadap Kecurangan Akademik Mahasiswa (Studi Empiris Pada Mahasiswa Universitas Pendidikan Ganesha Dan Sekolah Tinggi Keguruan Dan Ilmu Pendidikan Agama Hindu Singaraja). Jurnal Ilmiah Mahasiswa Akuntansi, 8(2), pp. 10-19.

Herman, S., 2008. Manajemen Sumber Daya Manusia. Yogyakarta: Graha Ilmu.

Hester, J. P. \& Killian, R. D., 2010. The Moral Foundation of Ethical Leadership. The Journal of ValueBased Leadership, 3(1), pp. 7-19.

Hollander, E. P. \& Julian, J. W., 2019. Contemporary trends in the analysis of leadership processes. Psychological Bulletin, 71(5), pp. 387-397.

Homedes, N. \& Ugalde, A., 2014. Neoliberal Reforms In Health Services In Latin America: A Critical View From Two Case Studies. American Journal of Public Health, 17(3), pp. 210-220.

Imamoglu, S. Z., Ince, H., Turkcan, H. \& Atakay, B., 2019. The Effect of Organizational Justice and Organizational Commitment on Knowledge Sharing and Firm Performance. Procedia Computer Science, 158(20), pp. 899-06.

Jaelani, A., 2020. Pengaruh Religuitas, Pengendalian Internal dan Budaya Organisasi terhadap Pencegahan Fraud dengan Dimoderasi oleh Work Family Conflit. Jurnal Ekonomi dan Bisnis, 6(2), pp. 26-32.

Jalaluddin, 2001. Psikologi Agama. Jakarta: Raja Grafindo Persada.

Karyono, 2013. Forensic Fraud. Yogyakarta: Andi.

Kosfeld, M. et al., 2005. Oxytocin increases trust in humans. Nature, 435(12), pp. 673-676.

Krishnan, V. R., 2005. Transformational leadership and outcomes: Role of relationship duration. Leadership \& Organization Journal, 26(5), pp. 442-457.

Kurniawan, G., 2013. Pengaruh Moralitas, Motivasi, dan Sistem Pengandalian Intern terhadap Kecurangan (Studi Empiris pada SKPD di Kota Solok). Jurnal Ekonomi Bisnis, 1(1), pp. 1-30.

Ladkin, D., 2008. Leading beautifully: How mastery, congruence and purpose create the aestic of embodied leadership practice. The Leadership Quarterly, 50(5), pp. 31-41. 
Laksmidewi, L., 2017. Evaluasi Implementasi Strategi Anti-Fraud (Studi Pada Pt Bank Bukopin Tbk). Universitas Brawijaya: Sarjana thesis.

Lambsdorff, J. G., 1999. Corruption in Empirical Research — A Review. [Online]

Available at: http://www.transparency.org.

[Diakses 28 September 2020].

Lapointe, E. \& Vandenberghe, C., 2018. Examination of the Relationships Between Servant Leadership, Organizational Commitment, and Voice and Antisocial Behaviors. Journal of Business Ethics, 109(14), pp. 301-307.

Levi, M., 2008. Organized frauds and organizing frauds: Unpacking the research on networks and group. Criminology and Criminal Justice, 8(4), pp. 389-419.

Luthans, F., 2005. Organizational Behavior. New York: McGraw-Hills.

Luz, C. M., Paula, S. L. \& Oliveira, L. M., 2018. Organizational commitment, job satisfaction and their possible influences on intent to turnover. Revista de Gestão, 5(1), pp. 84-101.

Mangkunegara, 2011. Manajemen Sumber Daya Perusahaan. Bandung: Remaja Rosdakarya.

Mayer, D. M. K. M. \& Greenbaum, R. L., 2010. Examining the link between ethical leadership and employee misconduct: the mediating role of ethical climate. Journal of Business Ethics, 9(5), pp. 7-16.

Milkovich, G. \& Newman, J., 2002. Compensation. Boston, MA: McGraw-Hill.

Mowday, R. T., Steers, R. M. \& Porter, L. W., 1979. The measurement of organizational commitment. Journal of Vocational Behavior, 14(5), pp. 224-247.

Nashori, F. \& Mucharam, R. D., 2002. Mengembangkan Kreativitas dalam Perspektif Psikologi Islam. Yogjakarta: Menara Kudus.

Nillsen, R., 2005. The Concept of Integrity in Teaching and Learning. Journal of University Teaching and Learning Practice, 5(2), pp. 1-10.

Nitisemito, A. S., 2014. Manajemen Personalia. Jakarta: Ghalia Indonesia.

Northouse, P. G., 2016. Leadership Theory and Practice Seventh Edition. Los Angeles, CA: SAGE Publications.

Pradanti \& Prastiwi, 2014. Analisis Pengaruh Love Of Money Terhadap Persepsi Etis Mahaiswa Akuntansi. Diponegoro Journal Of Accounting, 3(2), pp. 1-12.

Rahman, R. A. \& Anwar, I. S. K., 2014. Effectiveness of Fraud Prevention and Detection Techniques in Malaysian Islamic Banks. Procedia - Social and Behavioral Sciences, 14(5), pp. 97-102.

Risnawati, R. \& Ghufron, M. N., 2010. Teori-Teori Psikologi. Yogyakarta: Ar-. Ruzz Media Group.

Roach, C. F. \& Behling, O., 2014. Leaders and managers: International perspectives on managerial behavior and leadership. New York: Pergamon Press.

Robbins, S. P. \& Judge, T. A., 2013. Organizational Behavior. 15th Edition penyunt. New Jersey: Pearson Edication.

Robinson, S. L. \& Bennett, R. J., 1995. A typology of deviant workplace behavior: a multidimensional scaling study. The Academy of Management Journal, 38(2), pp. 555-572.

Rubenstein, C., 1981. Money and self-es teem, relationships, secrecy, envy, satisfaction. Psychology Today, 15(5), pp. 4-11.

Sardzoska, E. G. \& Tang, T. L., 2011. Work-Related Behavioral Intentions in Macedonia: Coping Strategies, Work Environment, Love of Money, Job Satisfaction, and Demographic Variables. Journal of Business Ethics, 10(8), pp. 373-391.

Schultz, D. \& Schultz, S. E., 2006. Psychology \& Work Today. New Jersey: Pearson Education, Inc.

Sedarmayanti, 2017. Manajemen Sumber Daya Manusia. Bandung: Refika Aditama.

Sekaran, U., 2012. Research Methods for Business. Jakarta: Salemba Empat.

Shadily, H., 1993. Sosiologi untuk Masyarakat Indonesia. Jakarta: Rineka Cipta.

Siregar, S. V. \& Tenoyo, B., 2015. Awareness Survey of Private Sector in Indonesia. Journal of Financial Crime, 22(3), pp. 329-346.

Stanford-Encyclopedia-of-Philosohy, 2016. Virtue Ethics. [Online]

Available at: https://plato.stanford.edu/entries/ethics-virtue/\#Virt 
[Diakses 28 September 2020].

Sudarsono, H., 2008. Bank \& Lembaga Keuangan Syari'ah. Yogyakarta: Ekonisia.

Sugiyono, 2015. Metode Penelitian Kuantitatif, Kualitatif dan R\&D. Bandung: Alfabet.

Suharto \& Suyanto, H. N., 2019. The Impact of Organizational Commitment on Job Performance. International Journal of Economics and Business Administration, 7(2), pp. 189-206.

Taherdoost, H., 2016. Validity and Realibility of the Reasearch Instrument; How to test the Validation of Questionnarie/Survey Research. International Journal of Academic Research in Management, 5(3), pp. 28-36.

Taiwo, A. S., 2009. The influence of work environment on workers productivity: A case of selected oil and gas industry in Lagos, Nigeria. African Journal of Business Management, 4(3), pp. 299-307.

Tang, T., 1992. The Meaning of Money Revisited. Journal of Organizational Behavior, 13(6), pp. 197202.

Tang, T. L.-P. \& Chen, Y.-J., 2007. Intelligence Vs. Wisdom: The Love of Money, Machiavellianism, and Unethical Behavior across College Major and Gender. Journal of Business Ethics, 82(5), pp. 1 26.

Tang, T. L. \& Chiu, R. K., 2003. Income, Money Ethic, Pay Satisfaction, Commitment, and Unethical Behavior: Is The Love of Money the Root of Evil for Hongkong Employees?. Journal of Business Ethics, 46(7), pp. 13-30.

Tang, T. L.-P., Luna-Arocas, R., Sutarso, T. \& Tang, D. S.-H., 2004. Does the love of money moderate and mediate the income-pay satisfaction relationship?. Journal of Managerial Psychology, 9(2), pp. 111-135.

Tenenhaus, M., Vinzi, V. E., Chatelin, Y. M. \& Lauro, C., 2005. PLS path modeling. Computational statistics \& data analysis, 48(1), pp. 159-205.

Toor, S.-u.-R. \& Ofori, G., 2009. Ethical Leadership: Examining the Relationships with Full Range Leadership Model, Employee Outcomes, and Organizational Culture. Journal of Business Ethics, 2(1), pp. 1-16.

Trice, H. M. \& Beyer, J. M., 1991. Cultural leadership in organizations. Organization Science, 2(2), p. 149-169.

Tuanakotta, T. M., 2007. Akuntansi Forensik dan Audit Investigatif. Jakarta: Lembaga Penerbit Fakultas Ekonomi Universitas Indonesia.

Twardowski, J., 2015. 10 Characteristics of Good Relationship. [Online]

Available at: http://www.huffingtonpost.com

[Diakses 28 September 2020].

Wells, J. T., 1997. Occupational Fraud and Abuse. Dexter, MI: Obsidian.

Wicaksono, A. P. \& Urumsah, D., 2016. Factors Influencing Employees To Commit Fraud in Workplace Empirical Study in Indonesian Hospitals. Asia Pasific Fraud Journal, 1(1), pp. 1-18.

Widiyanta, A., 2005. Sikap Terhadap Lingkungan dan Religiusitas. Jurnal Psikologi, 1(2), pp. 1-10.

Williams, B., 1981. Moral Luck: Philosophical Papers 1973-1980. Cambridge: Cambridge University Press..

Yates, L., 2014. Exploring the Relationship of Ethical Leadership with Job Satisfaction, Organizational Commitment, and Organizational Citizenship Behavior. The Journal of Values-Based Leadership, 7(1), pp. 12-22.

Yilmaz, O. \& Bahcekapili, H. G., 2015. Without God, everything is permitted? The reciprocal influence of religious and metaethical beliefs. Journal of Experimental Social Psychology, 5(8), pp. 95100.

Yousef, D. A., 2016. Organizational Commitment, Job Satisfaction and Attitudes toward Organizational Change: A Study in the Local Government. International Journal of Public Administration, 12(3), pp. 77-88.

Yozgat, U. \& Mesekiran, G., 2016. The Impact of Perceived Ethical Leadership and Trust in Leader on Job Satisfaction. Journal of Economics, Business and Management, 4(2), pp. 50-61. 
Ziegenfuss, D. E., 1996. State and Local Government Fraud Survey for 1995. USA: MCB University Press.

Zulaikha \& Hadiprajitno, P. B., 2016. Faktor-faktor yang mempengaruhi procurement fraud: sebuah kajian dari perspektif persepsian auditor eksternal. Jurnal Akuntansi dan Keuangan Indonesia, 13(3), pp. 194-220. 